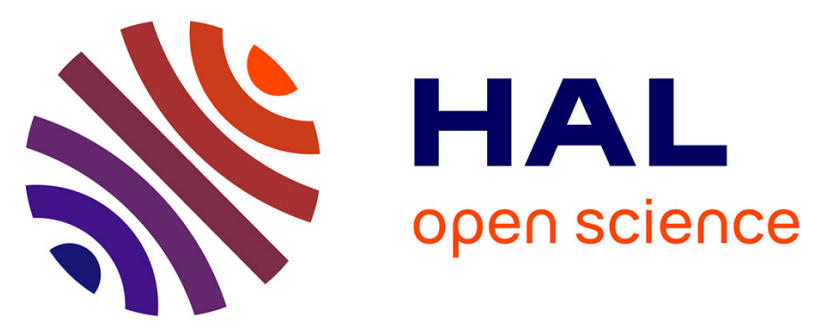

\title{
Tracing the sources and cycling of phosphorus in river sediments using oxygen isotopes: Methodological adaptations and first results from a case study in France
} Pistocchi Chiara, Federica Tamburini, Gérard Gruau, André Ferhi, Dominique Trevisan, Jean-Marcel Dorioz

\section{To cite this version:}

Pistocchi Chiara, Federica Tamburini, Gérard Gruau, André Ferhi, Dominique Trevisan, et al.. Tracing the sources and cycling of phosphorus in river sediments using oxygen isotopes: Methodological adaptations and first results from a case study in France. Water Research, 2017, 111, pp.346-356. 10.1016/j.watres.2016.12.038 . insu-01424862

\section{HAL Id: insu-01424862 \\ https://hal-insu.archives-ouvertes.fr/insu-01424862}

Submitted on 3 Jan 2017

HAL is a multi-disciplinary open access archive for the deposit and dissemination of scientific research documents, whether they are published or not. The documents may come from teaching and research institutions in France or abroad, or from public or private research centers.
L'archive ouverte pluridisciplinaire HAL, est destinée au dépôt et à la diffusion de documents scientifiques de niveau recherche, publiés ou non, émanant des établissements d'enseignement et de recherche français ou étrangers, des laboratoires publics ou privés. 


\section{Accepted Manuscript}

Tracing the sources and cycling of phosphorus in river sediments using oxygen isotopes: Methodological adaptations and first results from a case study in France

Pistocchi Chiara, Federica Tamburini, Gerard Gruau, André Ferhi, Dominique Trevisan, Jean-Marcel Dorioz

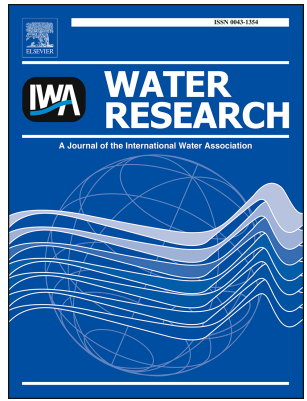

PII:

S0043-1354(16)30982-4

DOI: 10.1016/j.watres.2016.12.038

Reference: WR 12588

To appear in: Water Research

Received Date: 10 June 2016

Revised Date: 22 December 2016

Accepted Date: 23 December 2016

Please cite this article as: Chiara, P., Tamburini, F., Gruau, G., Ferhi, A., Trevisan, D., Dorioz, J.-M., Tracing the sources and cycling of phosphorus in river sediments using oxygen isotopes: Methodological adaptations and first results from a case study in France, Water Research (2017), doi: 10.1016/ j.watres.2016.12.038.

This is a PDF file of an unedited manuscript that has been accepted for publication. As a service to our customers we are providing this early version of the manuscript. The manuscript will undergo copyediting, typesetting, and review of the resulting proof before it is published in its final form. Please note that during the production process errors may be discovered which could affect the content, and all legal disclaimers that apply to the journal pertain. 
Dev. from equilibrium

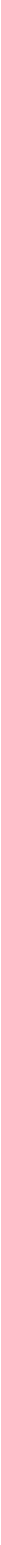


1 Tracing the sources and cycling of phosphorus in river sediments using oxygen isotopes: methodological adaptations and first results from a case study in France Pistocchi Chiara ${ }^{1}{ }^{*}$, Federica Tamburini ${ }^{1}$, Gerard Gruau ${ }^{2}$, André Ferhi $^{3}$, Dominique Trevisan $^{4}$, Jean-Marcel Dorioz ${ }^{4}$

$6 \quad{ }^{1}$ Group of Plant Nutrition, Inst. Of Agricultural Sciences, Swiss Federal Institute of Technology (ETH Zürich)

${ }^{2}$ CNRS-Université de Rennes I, UMR Géosciences Rennes

${ }^{3}$ UPMC - Université Pierre et Marie Curie - Paris 6

${ }^{4}$ INRA, UMR Carrtel

Abstract

An essential aspect of eutrophication studies is to trace the ultimate origin of phosphate ions (P$\mathrm{PO}_{4}$ ) associated with the solid phase of river sediments, as certain processes can make these ions available for algae. However, this is not a straightforward task because of the diversity of allochthonous and autochthonous sources that can supply $\mathrm{P}_{-} \mathrm{PO}_{4}$ to river sediments as well as the existence of in-stream processes that can change the speciation of these inputs and obscure the original sources. Here, we present the results of a study designed to explore the potentials,

19 limitations and conditions for the use of the oxygen isotope composition of phosphate $\left(\delta^{18} \mathrm{Op}\right)$ extracted from river sediments for this type of tracing. We first tested if the method commonly

21 applied to soils to purify $\mathrm{P}_{-} \mathrm{PO}_{4}$ and to measure their $\delta^{18} \mathrm{Op}$ concentrations could be adapted to sediments. We then applied this method to a set of sediments collected in a river along a gradient of anthropogenic pressure and compared their isotopic signatures with those from

\footnotetext{
* Corresponding author.

E-mail address: Chiarapi@ethz.ch
} 
samples that are representative of the potential $\mathrm{P}-\mathrm{PO}_{4}$ inputs to the river system (soils and riverbank material).

The results showed that following some adaptations, the purification method could be successfully transposed to river sediments with a high level of $\mathrm{P}_{-} \mathrm{PO}_{4}$ purification (> 97\%) and high $\delta^{18}$ Op measurement repeatability and accuracy $(<0.4 \% o)$. The values for the potential allochthonous sources varied from 11.8 to $18.3 \%$, while the $\delta^{18}$ Op value for the river sediments ranged from 12.2 to $15.8 \%$. Moreover, a sharp increase (> 3\%o) in the sediment $\delta^{18}$ Op value immediately downstream from the discharge point revealed the strong impact of municipal wastewater. The calculation of the theoretical equilibrium $\delta^{18} \mathrm{O}_{\mathrm{p}}$ values using the river water temperature and $\delta^{18} \mathrm{O}_{\mathrm{w}}$ showed that the downstream sediments were in equilibrium, which was not the case for the upstream sediments. This difference could be related to the contrast between the short residence time of the transfer system in the catchment head, which can preserve the isotopic variability of the source materials, and the longer residence times and higher $\mathrm{P}$ bioavailability in the lower catchment, possibly fostering the recycling of $\mathrm{P}_{-} \mathrm{PO}_{4}$ by the biota and the equilibration of the oxygen isotope signature in $\mathrm{P}_{-} \mathrm{PO}_{4}$. These results demonstrate the potential of the isotopic approach to assess the sources and in-stream turnover of sedimentary $\mathrm{P}$ in river systems.

KEYWORDS: Phosphorus transfer, Agriculture, In-stream processes, Eutrophication, Phosphate oxygen isotopes

\section{Introduction}

7 Phosphorus (P) associated with the solid phase and designated as "particulate-P" often accounts for the major part of phosphorus transferred from terrestrial to aquatic ecosystems (Kleinman et 
al., 2011; Kronvang et al., 2007; Sharpley et al., 1999). The impact of particulate-P on the trophic state and eutrophication of the receiving aquatic ecosystems, especially lentic ecosystems, depends on the size of its potentially bioavailable fraction. The amount of $\mathrm{P}$ that occurs as inorganic phosphate ions ( $\mathrm{P}-\mathrm{PO}_{4}$ pools), either in solution (dissolved $\left.\mathrm{P}_{-} \mathrm{PO}_{4}\right)$, sorbed onto, or precipitated within stream and river sediments, is thought to represent the most readily bioavailable P pool (Moorleghem et al., 2013). Therefore, an essential aspect of studies dedicated to the restoration of eutrophicated aquatic ecosystems is to quantify $\mathrm{P}-\mathrm{PO}_{4}$ pools in river water and sediments and to trace the ultimate origin of these pools (Kleinman et al., 2011; Mellander et al., 2015).

However, this quantification is not a straightforward task because of the diversity of the allochthonous and autochthonous sources that may supply $\mathrm{P}-\mathrm{PO}_{4}$ to river sediments. Several allochthonous compartments in the catchment can supply particulate-P to river sediments, including pristine and weathered basement rocks, forested or agricultural soils, riverbank sediments, etc. For example, the autochthonous addition of $\mathrm{P}-\mathrm{PO}_{4}$ to the sediments can occur through sorption onto the sediments of dissolved $\mathrm{P}_{-} \mathrm{PO}_{4}$ ions supplied by sewage effluents or the in-stream mineralization of sewage organic matter (Poulenard et al., 2008). The in-stream retention of dissolved $\mathrm{P}_{-} \mathrm{PO}_{4}$ by the sediments primarily occurs during low-flow periods when the retention time of the sediment is long enough to allow the necessary physical-chemical reactions to develop (Dorioz et al., 1998a, 1989; Ensign et al., 2006; Pistocchi et al., 2012) and is particularly intense immediately downstream of the point source pollution inputs. Autochthonous $\mathrm{P}_{-} \mathrm{PO}_{4}$ pools can also come from the recycling of allochthonous particulate-P by aquatic flora or by microorganisms in the sediment. The biological uptake by biofilm is another important seasonal process that is involved in the retention of $\mathrm{P}-\mathrm{PO}_{4}$ ions by the sediment (Wang et al., 1999). These in-stream recycling and retention processes, which help the $\mathrm{P}$ to turn over within the river ecosystem, are expected to be triggered by the bioavailability of 
allochthonous $\mathrm{P}$ and to regulate the internal productivity of the river system. Their quantification can be used to assess the efficiency of a river system to recycle and transform any particulate $\mathrm{P}$ into more bioavailable $\mathrm{P}-\mathrm{PO}_{4}$, but an efficient recycling can eventually obscure the ultimate origin of the $\mathrm{P}-\mathrm{PO}_{4}$ exported at the outlet.

It is often impossible to quantify and trace the different sources of particulate-P that are potentially involved in eutrophication using only the variability in $\mathrm{P}$ speciation as determined by classical chemical extraction methods (Burrus et al., 1989; Pacini and Gächter, 1999; Poulenard et al., 2009; Walling et al., 2008). As a result, there a need to develop tools or/and strategies that can be reliably used to trace this important $\mathrm{P}$ compartment, particularly its dominant inorganic $\mathrm{P}-\mathrm{PO}_{4}$ fraction, and to understand the extent and rate at which particulate-P is biologically recycled and modified within streams and rivers.

Oxygen isotopes could provide one such possible tool. The oxygen isotopic composition of phosphate $\left(\delta^{18} \mathrm{Op}\right)$ has already been successfully used to trace $\mathrm{P}$ sources and study the $\mathrm{P}-\mathrm{PO}_{4}$ cycle in soils, freshwater and marine sediments (Davies et al., 2014; Goldhammer et al., 2011; Gooddy et al., 2016; Gruau et al., 2005; Melby et al., 2013; Tamburini et al., 2014). This approach is based on: i) the existence of measurable differences in the abundance ratio for ${ }^{18} \mathrm{O}$ and ${ }^{16} \mathrm{O}$ atoms in the phosphate group of potential $\mathrm{P}-\mathrm{PO}_{4}$ sources (e.g. primary P-rich minerals, chemical fertilizers, chemical detergents, phosphate from wastewater, etc.); and ii) the fact that biologically mediated processes have the possibility to modify $\delta^{18} \mathrm{Op}$ in a predictable way (Blake et al., 2005). The first property allows the oxygen isotope composition of $\mathrm{P}_{-} \mathrm{PO}_{4}$ to be potentially used as a source tracer in environmental systems, whereas the second property allows it to be used to quantify the rate of biological recycling of $\mathrm{P}_{-} \mathrm{PO}_{4}$. Two enzymatic processes are mainly responsible for changes in the $\delta^{18} \mathrm{Op}$ value. One is the isotope equilibration between oxygen in $\mathrm{P}_{-} \mathrm{PO}_{4}$ and oxygen in ambient water. This process, which is caused by reversible phosphorylation/dephosphorylation reactions that are catalyzed by the 
inorganic intracellular pyrophosphatase enzyme (Blake et al., 2005), is temperature dependent and has been described by an empirical equation (Longinelli and Nuti, 1973) that was recently revised by Chang and Blake (2015). The second is the kinetic isotope fractionation produced by the enzymatic hydrolysis of phosphoesters (Liang and Blake, 2006; von Sperber et al., 2015, 2014), the magnitude of which depends on the type of enzyme involved (e.g. acid or alkaline phosphatases) and the final effect of which on the isotopic signature of the recycled $\mathrm{P}_{-} \mathrm{PO}_{4}$ also depends on the $\delta^{18}$ Op value for the original substrate, i.e. inheritance effect (Liang and Blake, 2006). Small kinetic isotope effects are associated with the initial stages of the abiotic reaction, such as the sorption of $\mathrm{P}_{-} \mathrm{PO}_{4}$ onto the solid phases (Jaisi et al., 2010; Melby et al., 2013b) or biological uptake (Blake et al., 2005).

In freshwater ecosystem studies, the use of $\delta^{18} \mathrm{Op}$ is at an early stage (Davies et al., 2014). For river sediments, the lack of a standardized method to extract, purify and analyze $\delta^{18} \mathrm{Op}$ is a hinderance. In this study, we first adapted the method that is commonly used for soils to sediments and validated the capability of this method to provide precise and accurate results. We then applied this method to riverbed sediments from a river in the French Alps with the following objectives: i) to characterize the variability of the $\delta^{18} \mathrm{Op}$ signatures in the riverbed sediments and the potential external sediment sources (soils, riverbank materials) in an exemplar river system; ii) to explore the potential, limitations and conditions of using the isotopic tool to assess the respective role of external inputs and internal recycling processes to build up the $\mathrm{P}-\mathrm{PO}_{4}$ budget of the riverbed sediments in this river.

\section{Materials and methods}

\subsection{Site description and sampling}



[Figure 1]

The Redon River is a small alpine torrential tributary (i.e. a shallow high-gradient, high-energy stream with an annual average discharge of $0.5 \mathrm{~m}^{3} / \mathrm{s}$ at the outlet) of Lake Geneva (France). The sediment dynamic of this river has been already intensively studied (Al-Charideh, 1988; Dorioz et al., 1998b; Feuillade and Dorioz, 1992; Hamid et al., 1989; Poulenard et al., 2008) making it a particularly appropriate site for the present exploratory study. The total catchment surface area is 3,300 ha with a land use that consists mainly of forests $(1,100$ ha) in its upland part and grasslands (1,200 ha) and cultivated farmlands (300 ha) in its lowland part. Several wetlands (20 ha) are present, while urbanized areas are concentrated near the outlet, close to the shore of Lake Geneva. The Redon River is impacted by both point and diffuse sources of P. The main point source of $\mathrm{P}$ is located in the lower part of the river and consists of inputs of predominantly dissolved P from a wastewater treatment plant (WWTP), whereas the main diffuse sources occur in the upper part of the catchment, consisting mainly of particulate-P from agricultural and forested lands (Fig. 1).

The soils are mainly Cambisols, formed from the weathering products of quaternary moraine material consisting of a large range of mainly calcareous sedimentary, metamorphic and igneous rocks from the Rhône glacier (Nicoud et al., 1993). The soil mineralogy is comprised of a mixture of minerals inherited from the weathering of this heterogeneous parent material and their secondary weathering products. Previous studies (Dorioz et al., 1998a, 1998b) have shown that the Redon River sediments are $\mathrm{CaCO}_{3}$-rich (10 to $20 \% \mathrm{CaCO}_{3}, \mathrm{pH}>7$ ). Their fine $(<200 \mu)$ fraction is dominated by loamy and sandy materials, with an organic matter content between 2 to $4.5 \%$. The clay fractions (7-11\%) consist mostly of soil-derived illite, biotite and chlorite (Poulenard et al., 2008). The water in the Redon River is bicarbonated-calcic. 


\subsection{Sampling strategy and sample preparation}

149 Details regarding the sampling sites and sampling conditions are given in Tables 1 and 2. Three types of samples were collected: i) eight riverbed sediments collected at six locations (A, B, C, D, E and F in Fig. 1) along a downstream gradient of land use that changes from forested to

152

153 mixed agricultural/urban areas, thus representing a gradient of increasing anthropogenic pressure; this includes two samples collected in streamlets draining a small agricultural subcatchment (locations A and B in Fig. 1) that is representative of the type of agriculture practiced in the Redon River catchment (Dorioz and Ferhi, 1994); ii) four samples representative of the potential sources of river sediments, including cultivated topsoil and deep horizon, riverbank material, and soil from a 2 ha wetland, hydraulically connected to the river; and iii) two samples from sediments from Lake Geneva representing an average reference for the local superficial lacustrine sediments (collected in 2012 and provided by the EDYTEM laboratory).

Given that it was difficult to access the river bed, it was not possible to visit all six riverbed sediment sampling locations at the same time. Three locations were first sampled at the end of March 2012 (B, C and F), and five (A, B, D, E and F) were sampled (again) at the beginning of September 2012. Both periods were low-flow periods, where the September period corresponds to the lowest weekly discharge period of the year. Samples were taken in areas of preferential accumulation of fine sediments. At each location, single samples of the entire sediment matrix were taken manually at 3-5 different points and then mixed to obtain an average sample (0.5-1 kg dry weight). Simultaneously, the electric conductivity (EC) was measured and a water sample was collected to determine the SRP (soluble reactive phosphorus) concentration and water oxygen isotope composition $\left(\delta^{18} \mathrm{O}_{\mathrm{w}}\right)$. Hourly water temperatures were obtained from automatic recorders at the outlet. The riverbank sample was collected in the upstream, forested part of the catchment (see Fig. 1). The cultivated soil samples were collected in the same small 
173 sub-catchment used to sample the streamlet sediments (Fig. 1), as this sub-catchment is known

174 to represent zones of maximum soil erosion risk in the Redon catchment (Dorioz and Ferhi,

175 1994). In addition to taking a topsoil sample, a deeper soil sample was taken at a depth of

176 approximately $-70 \mathrm{~cm}$ to account for the possible erosion of deep soil materials along ditches

177 or/and soil embankments. These two samples were obtained by pooling five subsamples (200-

$178300 \mathrm{~g}$ ) collected in different locations within a single field or its embankment. The pooled

179 samples were then air-dried and sieved at $200 \mu \mathrm{m}$ before analysis. No river water samples were

180 collected for the analysis of the $\delta{ }^{18}$ Op values for the dissolved $\mathrm{P}_{-} \mathrm{PO}_{4}$, although these could

181 have been useful in the interpretation of the riverbed sediment data. The decision not to sample

182 the river water was due to the very low concentrations of dissolved $\mathrm{P}-\mathrm{PO}_{4}$ recorded in this river

183 (Table 1), which makes it extremely difficult to analyze the $\delta^{18} \mathrm{Op}$ in the current state of the 184 analytical protocols.

185

186 [Table 1]

187

188 [Table 2]

189

190

\subsection{Sediment and soil $P$ chemical analyses}

191

192 The total phosphorus $(\mathrm{Pt})$ and Olsen $\mathrm{P}\left(\mathrm{P}_{\mathrm{Olsen}}\right)$ concentrations were determined in all of the

193 samples. $\mathrm{P}_{\text {Olsen }}$ (Olsen et al., 1954), which is considered as being representative of the

194 bioavailable fraction of $\mathrm{P}$ in soils, has been shown to correlate linearly with P extracted from

195 the sediment in bio-assays with algae (Jordan-Meille, 1998). The Pt concentrations were

196 measured after a hot sodium hydroxide digestion. The total inorganic and organic $\mathrm{P}$ in the

197 samples were determined according to Saunders and Williams (1955) as described by Fares et 
al. (1974). The spectrophotometric determination of $\mathrm{P}-\mathrm{PO}_{4}$ in all of the extracts/digestates was carried out using the molybdenum blue method (Murphy and Riley, 1962) at $882.0 \mathrm{~nm}$ on a Cary $50 \mathrm{UV}-\mathrm{Vis}$ spectrometer (Agilent).

\subsection{Isotopic analyses and data treatment}

\subsubsection{Extraction and purification protocol}

204 We used the extraction and purification protocol initially developed by Tamburini et al. (2010)

205 for soils (hereafter referred as to Tb10), which we adapted for sediments. The Tb10 protocol 206 consists of the following six steps:

207 i) extraction of phosphate from the soil/sediment with $1 \mathrm{M} \mathrm{HCl}$, which in sequential extraction 208 mainly targets the $\mathrm{P}_{-} \mathrm{PO}_{4}$ pool (HCl-P) associated with $\mathrm{Ca}$, but in our case (singular extraction) 209 also P sorbed onto Fe and $\mathrm{Al}$ oxides;

210 ii) dissolved organic matter (DOM) removal from the solution using an Amberlite resin,

211 iii) ammonium phospho-molybdate (APM) precipitation and subsequent dissolution,

212 iv) magnesium ammonium phosphate (MAP) precipitation and dissolution,

213 v) cation removal by a cation exchange resin (BioRad, AG50 x8),

214 vi) silver phosphate $\left(\mathrm{Ag}_{3} \mathrm{PO}_{4}\right)$ precipitation through the addition of an Ag-ammine solution to 215 the purified phosphate solution.

216 The goal of these steps, after $\mathrm{HCl}$ extraction, is to avoid sources of oxygen (i.e. DOM, nitrate, 217 etc.) other than $\mathrm{P}_{-} \mathrm{PO}_{4}$ and other contaminants, e.g. chloride, in the final silver phosphate 218 precipitate.

219 We modified the Tb10 protocol in several ways as follows (Fig. 2 in the supplementary 220 material). First, the samples were sieved at $200 \mu \mathrm{m}$ instead of $2 \mathrm{~mm}$, since this finer fraction 221 contains the bulk of the bio-geochemically active P in river sediments (Poulenard et al., 2008). 222 The liquid-to-solid ratio in the extraction step was modified to 100:1 instead of 50:1, since the 
pre-tests showed that, with our highly carbonated sediments, the solution did not reach the targeted $\mathrm{pH}(1 \pm 0.5)$. The quantity of sediment was adjusted to have at least $10 \mu$ moles of $\mathrm{P}$ for the purification, corresponding to 10 to $20 \mathrm{~g}$ of sieved sediments. The DOM removal step using an Amberlite resin was not performed as the subsequent steps successfully eliminated the organic matter (see below). Finally, for samples with a high calcium carbonate content, an additional step had to be introduced to account for the formation of a calcium molybdate precipitate during the APM precipitation. To eliminate the precipitate, we repeated the subsequent MAP precipitation step twice.

The $1 \mathrm{M} \mathrm{HCl}$ extraction may hydrolyze some of the organic or condensed P (Turner et al., 2005) and the released Pi may bias the isotopic composition of the inorganic P pool targeted here. To assess the existence of such a possible artifact, extractions were run in duplicate using ${ }^{18} \mathrm{O}$-labeled and unlabeled reagents. $\mathrm{An}^{18} \mathrm{O}$-labelled $1 \mathrm{M} \mathrm{HCl}$ solution was prepared by adding approximately $0.05 \mathrm{ml}$ of ${ }^{18} \mathrm{O}$-enriched water (97\%o, Aldrich) to 1 liter of $1 \mathrm{M} \mathrm{HCl}$ solution. Labeled and unlabeled solutions were analyzed for $\delta^{18} \mathrm{O}_{\mathrm{w}}$. If hydrolysis occurred, it should result in different isotopic compositions depending on whether labeled or unlabeled reagents were used, i.e. a higher $\delta^{18} \mathrm{O}_{\mathrm{p}}$ for the labeled sample compared to the unlabeled one. In this case, we calculated the "real" isotopic value by a revised version of the mass balance equation used by McLaughlin et al. (2006b):

$\delta 180 p=\frac{\left(\delta 18 O_{p l} \cdot \delta 18 O_{w n l}-\delta 18 O_{p n l} \cdot \delta 18 O_{w l}\right)}{\left(\delta 18 O_{p l}-\delta 18 O_{p n l}-\delta 18 O_{w l}+\delta 18 O_{w n l}\right)}$

242 where $\delta^{18} \mathrm{O}_{\mathrm{pl}}$ and $\delta^{18} \mathrm{O}_{\mathrm{pnl}}$ are the isotopic composition of $\mathrm{P}-\mathrm{PO}_{4}$ for the labeled and unlabeled 243 samples, respectively, and $\delta^{18} \mathrm{O}_{\mathrm{wl}}$ and $\delta^{18} \mathrm{O}_{\mathrm{wnl}}$ are the isotopic composition of water for the 244 labeled and unlabeled reagents, respectively.

245 The efficiency and reliability of the modified Tb10 protocol used here were evaluated by 246 considering the repeatability of the extraction/purification process, the final $\mathrm{Ag}_{3} \mathrm{PO}_{4}$ yield and 247 its purity. The purity was assessed by i) dissolving the obtained $\mathrm{Ag}_{3} \mathrm{PO}_{4}$ and comparing the 
actual concentration of phosphate in the solution with the theoretical concentration, i.e. the

amount expected if all of the solid mass was $\mathrm{Ag}_{3} \mathrm{PO}_{4}$, and ii) determining the $\mathrm{C}$ and $\mathrm{N}$

concentration of the obtained $\mathrm{Ag}_{3} \mathrm{PO}_{4}$ on the elemental analyzer (Flash 2000, Termo

Scientific); these two concentrations are used as indicators of possible contamination by

through quantification of the oxygen yield during mass spectrometry analyses. This was done by graphically comparing the weight of the $\mathrm{Ag}_{3} \mathrm{PO}_{4}$ standards and samples introduced into the machine against the peak area of the produced CO ("oxygen yield"), which is proportional to the oxygen content in the sample. If other sources of oxygen or contaminants were present in the sample, the oxygen yield should be different from the standard $\mathrm{Ag}_{3} \mathrm{PO}_{4}$. $\mathrm{P}-\mathrm{PO}_{4}$ losses at each step of the purification were also quantified (see Pistocchi et al. 2014 for more details).

\subsubsection{Isotopic analyses and calculation of the theoretical equilibrium values}

The oxygen isotope composition of the purified $\mathrm{Ag}_{3} \mathrm{PO}_{4}$ was measured using a thermal

isotopic ratio mass spectrometer (IRMS) at the Plant Nutrition Group laboratory (ETH Zurich).

Two to three replicates of each sample were weighed (300 to $600 \mu \mathrm{g}$ ) in silver capsules with a

264 small added amount of glassy carbon powder. The temperature of the TC/EA furnace was kept at $1450^{\circ} \mathrm{C}$ for pyrolysis.

266 During each run, repeated measurements of an internal standard (Acros Organics $\mathrm{Ag}_{3} \mathrm{PO}_{4}>$ $97.5 \%, \delta^{18} \mathrm{O}_{\mathrm{p}}=+14.2 \%$ ) and two international benzoic acid standards (IAEA 601 and IAEA $602, \delta^{18} \mathrm{O}=+23.3 \%$ and $+71.4 \%$, respectively, IAEA, Vienna, Austria) were included and used to calibrate and correct the instrumental drift. The $\delta^{18} \mathrm{O}_{\mathrm{p}}$ values presented in this paper are reported in the standard $\delta$ notation with respect to VSMOW (Vienna Standard Mean Oceanic

271 Water), i.e. as \%o deviation values. Analytical uncertainties, as determined from the replicate

272 analysis of the standards, were estimated to be below $0.3 \%$. 
273 In order to assess the extent to which the sedimentary $\mathrm{P}-\mathrm{PO}_{4}$ pools investigated in this study

274 could be secondary recycled $\mathrm{P}-\mathrm{PO}_{4}$ (i.e. $\mathrm{P}-\mathrm{PO}_{4}$ that has been cycled by the river biota), a

275 theoretical equilibrium $\delta^{18} \mathrm{O}_{\mathrm{p}}$ value - i.e. the oxygen isotopic composition the phosphate should

276 have if it is in equilibrium with the ambient water - was calculated for each sample using the

277 following equation (Chang and Blake, 2015):

$\delta 18 O_{p}=\left(\delta 18 O_{w}+10^{3}\right) \cdot e^{\frac{\left[\left(14.43 \cdot \frac{10^{3}}{T}\right)-26.54\right]}{10^{3}}}-10^{3}$

where $\delta^{18} \mathrm{Op}$ is the calculated oxygen isotopic composition of the $\mathrm{P}_{-} \mathrm{PO}_{4}$ sample at equilibrium in $\% o, \delta^{18} \mathrm{O}_{\mathrm{w}}$ is the measured oxygen isotopic composition of the water in $\%$, and $\mathrm{T}$ is the temperature in degrees Kelvin.

Considering the stability of the $\delta^{18} \mathrm{O}_{\mathrm{w}}$ values during low-flow periods in the Redon River due to the dominance of the ground water contribution to the discharge during these periods (AlCharideh, 1988), we used the $\delta^{18} \mathrm{O}_{\mathrm{w}}$ of the river water measured at each sampling date as the reference isotopic value for water in equation 2 . We considered both the minimum and maximum temperatures measured over the period running between the sampling date and the closest big storm flow event (around 10-20 days; Table 1 in the Supplementary Material), since the sediments are (partially) renewed at each storm flow. The temperatures measured at the time of sampling fell within these ranges. For samples 9 to 12 (sources), we used the $\delta^{18} \mathrm{O}_{\mathrm{w}}$ values measured in the local water sources, including rain, groundwater and soil water data, and the extremes for the soil temperature measured within the previous 10 days at an agrometeorological station close to the studied sites. This allowed us to have a conservative and time-integrated estimate of the equilibrium interval. For these samples, we also calculated the deviation from equilibrium using the average stream water temperature and isotopic composition, to verify whether or not their $\delta^{18} \mathrm{O}_{\mathrm{p}}$ values would fall within the equilibrium range 
as the interval (in \%o) between the measured $\delta^{18} \mathrm{O}_{\mathrm{p}}$ values and the closest values for the equilibrium range calculated from equation 2

\section{Results}

\subsection{Method validations}

304 Repeated extractions and purifications ( $n=3$ or 4$)$ on the same sediment sample yielded $\delta^{18} \mathrm{Op}$

305 values with a standard deviation $<0.4 \%$. This repeatability can be considered as acceptable,

306 since it is within the range of the precision obtained on the repeated standards measurements on 307 the TC/EA-IRMS.

308 The purity of $\mathrm{Ag}_{3} \mathrm{PO}_{4}$ was $97 \%$, as determined by analyzing the $\mathrm{P}^{-\mathrm{PO}_{4}}$ in the redissolved $309 \mathrm{Ag}_{3} \mathrm{PO}_{4}$ (see section 2.3.1, Table 2 in the Supplementary Material). The carbon and nitrogen 310 concentrations were generally lower than $1 \%$ and $0.1 \%$, respectively (Table 2 in the

311 Supplementary Material). The $\mathrm{C}$ content was comparable to that measured in the internal 312 standard $\mathrm{Ag}_{3} \mathrm{PO}_{4}(0.5 \%)$ and much lower than the $23-29 \%$ or $0.2 \%$ reported by Weiner et al. 313 (2011) for $\mathrm{C}$ and $\mathrm{N}$, respectively. The efficiency of the purification procedure was confirmed 314 by the oxygen yield given by the mass spectrometer (Fig. 1 in the Supplementary Material). All 315 of the samples were close to the regression line defined by the $\mathrm{Ag}_{3} \mathrm{PO}_{4}$ standards, indicating 316 that the amount of oxygen in the samples was close to the stoichiometry of the pure compound. 317 Most of the labeled/unlabeled pairs did not show significantly different $\delta^{18} \mathrm{O}_{\mathrm{p}}$ values. Only four 318 samples (2, 5, 8 and 9) showed different labeled and unlabeled values, meaning that the organic $319 \mathrm{P}$ or condensed phosphate was hydrolyzed during the $\mathrm{HCl}$ extraction. These values have been corrected with equation 1 , as all of the other values are the average of the labeled and unlabeled results. 
324 Table 3. P speciation and isotopic data

The P content and speciation varied strongly from one sample to another, with the Pt value ranging from 459 to $1256 \mathrm{mgP} / \mathrm{kg}$, Pi from 179 to $631 \mathrm{mgP} / \mathrm{kg}$ and Po from 36 to $450 \mathrm{mgP} / \mathrm{kg}$. $\mathrm{P}_{\text {Olsen }}$ accounted for 0.7 to $10.6 \%$ of $\mathrm{Pt}$ depending on the samples. The highest $\mathrm{P}_{\text {Olsen }}$ concentrations $(65-67 \mathrm{mgP} / \mathrm{kg}$, representing 8.4 to $10.6 \%$ of $\mathrm{Pt})$ were found in the river sediments sampled immediately downstream from the WWTP discharge. These variations are the consequence of differences in the source, erosion and deposition conditions of the sediments as well as differences in the $\mathrm{P}$ inputs that accumulate along the river (Table 1). The downstream sediments (samples 5 to 8 ) and streamlet sediments (samples 1 and 2) were enriched in $\mathrm{Pt}, \mathrm{Pi}$ and $\mathrm{P}_{\mathrm{Olsen}}$ compared to the sediments coming from the head of the catchment (samples 3) or to the riverbank material (sample 12). The same relative enrichment is observed for the cultivated topsoil (sample 10) compared to its lower horizon (sample 11).

$\mathrm{Pt}$ and $\mathrm{P}_{\text {Olsen }}$ were weakly and positively correlated $\left(\mathrm{r}^{2}=0.49, \mathrm{p}<0.01\right)$ as well as the $\mathrm{P}_{\mathrm{Olsen}} / \mathrm{Pi}$ ratio with $\mathrm{Pt}$ concentrations of $\mathrm{r}^{2}=0.76(\mathrm{p}<0.01)$, providing evidence that the $\mathrm{P}$ enrichment process recorded by the downstream sediments is accompanied by an increase in the most reactive fraction of the total $\mathrm{P}-\mathrm{PO}_{4}$ pool. The highest Po concentrations were found in the topsoil samples (9 and 10).

\subsection{Measured isotopic signatures and comparison with the equilibrium values}

344 The measured $\delta^{18} \mathrm{O}_{\mathrm{p}}$ values for the $\mathrm{HCl}$ extracts varied between $+11.8 \%$ o (deep soil horizon, 345 sample 11) and $+18.3 \%$ o (wetland soil, sample 9; Fig. 2a). No significant statistical 346 relationships were found between the $\delta^{18} \mathrm{O}_{\mathrm{p}}$ values for the samples and their $\mathrm{Pt}, \mathrm{P}_{\mathrm{Olsen}}$ or Pi 347 content or ratios, nor with the water characteristics, notably the SRP concentrations. The 
riverbank sample collected in the head of the catchment (sample 12) corresponds to a weakly weathered moraine, as confirmed by field observations, i.e. no visible weathering and no vegetation or biofilm on the banks, since they are eroded at each storm flow, and by the $\mathrm{P}$ speciation data (very low $\mathrm{P}_{\text {Olsen }}$ and Po fractions; see Table 3). This sample is representative of both the principal source of the upstream, unpolluted sediments and the parent material of most of the soils in this catchment (CIPEL, 1988). Its $\delta^{18} \mathrm{O}_{\mathrm{p}}$ value $(+15.9 \%$ ) indicates that it has a mixed igneous/sedimentary origin, as this value is intermediate between the $\delta^{18} \mathrm{O}_{\mathrm{p}}$ values reported for igneous or metamorphic apatite (approximately $+7 \%$; Tamburini et al., 2012) and for sedimentary apatite (between +17 and $+23 \%$; Tamburini et al., 2014).

Interestingly, the variability in the $\delta^{18} \mathrm{O}_{\mathrm{p}}$ values for the allochthonous sources that may possibly contribute toward the river particulate-P load was higher than the variability in the riverbed

359 sediments. Whereas while the soil, riverbank and riverbed sediments collected in the head of 360 the catchment (samples 1 to 3 and 9 to 12) are representatives of these sources (Dorioz and 361 Ferhi, 1994) and exhibit $\delta^{18} \mathrm{O}_{\mathrm{p}}$ values varying by $>6 \%$ (from +11.8 to $+18.3 \%$ ), this variation 362 is reduced to approximately $2 \%$ o for the sediments immediately upstream/downstream the

363 WWTP and to $1 \%$ o for the outlet sediments $(+12.8$ to $+13.8 \%$; Fig. $2 \mathrm{a})$, the $\delta^{18} \mathrm{O}_{\mathrm{p}}$ signatures of 364 which were comparable to those recorded by the lake sediments (samples 13 and 14; Table 3).

368 We compared the measured $\delta^{18} \mathrm{O}_{\mathrm{p}}$ values with the theoretical equilibrium calculated with 369 Equation 2 (see Table 2). The deviation between the calculated and measured $\delta^{18} \mathrm{O}_{\mathrm{p}}$ values is 370 presented in Fig. 2b. The $\delta^{18} \mathrm{O}_{\mathrm{p}}$ value for the riverbank moraine sample (sample 12) was above 371 the calculated equilibrium by ca. $2 \%$, as was the wetland soil sample (9). This was not the case 372 for the cultivated soil samples that showed $\delta^{18} \mathrm{O}_{\mathrm{p}}$ values that were either very close to $(-0.1 \%$, 
topsoil, sample 10) or slightly lower than $(-0.7 \%$ o, deep horizon, sample 11$)$ the calculated equilibrium values.

The riverbed sediment samples collected in the streamlets of the agricultural sub-catchment (samples 1,2) exhibited $\delta^{18} \mathrm{O}_{\mathrm{p}}$ values that were lower than the calculated equilibrium values by ca. $2 \%$. For the sediments located within the main hydrogeological network, the differences between the measured and calculated equilibrium values generally tended to be lower (see Table 3 and Fig. 2 b): ca. $\pm 1.5 \%$ in the middle part, upstream and downstream from the WWTP discharge point (samples 4 to 6 ) and $<0.5 \%$ o for the sediments collected at the outlet (samples 7 and 8) and the lacustrine sediments (samples 13 and 14).

\section{Discussion}

\subsection{Significance and variability of the measured and equilibrium $\delta^{18} \mathrm{O}_{\mathrm{p}}$ values}

The present study shows that the method originally established and optimized by Tamburini et al. (2010) for soils is suitable for $\mathrm{CaCO}_{3}$-rich riverbed sediment samples, following some modifications to the methodology. However, as for soils, it should be kept in mind that the extraction is not entirely specific with regards to the nature of the extracted $\mathrm{P}-\mathrm{PO}_{4}$. First, $1 \mathrm{M}$ $\mathrm{HCl}$ can be used to extract the fraction that is primarily composed of $\mathrm{Ca}$-bound $\mathrm{P}$, which can contain a broad spectrum of $\mathrm{P}$ compounds (more or less crystallized apatite forms, $\mathrm{CaCO}_{3}-$ bound $\mathrm{P}$, etc.). This reagent can also extract some $\mathrm{P}-\mathrm{PO}_{4}$ sorbed onto $\mathrm{Fe}$ and $\mathrm{Al}$ oxides, if used as a single extractant. Thus, the $\delta^{18} \mathrm{O}_{\mathrm{p}}$ signatures obtained with this method correspond to a pooled $\mathrm{P}_{-} \mathrm{PO}_{4}$ isotope signature of a mixture of different $\mathrm{P}$ fractions with a different degree of stability, exchangeability and bioavailability (Jarvie et al., 2002) rather than to the signature of a geochemically specific $\mathrm{P}_{-} \mathrm{PO}_{4}$ compartment. Despite this limitation, the oxygen isotope composition of $\mathrm{P}_{-} \mathrm{PO}_{4}$ extracted from sediment using $\mathrm{HCl}$ can provide information that is not 
available with other methods, including the extent to which a P pool has been biologically

processed or derived from primary inputs or secondary anthropogenic sources (Tamburini et al., 2014; Davis et al., 2014).

401 The calculation of the equilibrium $\delta^{18} \mathrm{O}_{\mathrm{p}}$ values is another critical point for the interpretation of 402 the $\delta^{18} \mathrm{O}_{\mathrm{p}}$ isotope data. Information regarding the kinetics of the equilibrium is only derived 403 from cell-free or soil incubation experiments (Blake et al., 2005; Melby et al., 2013), but not 404 from conditions that are close to the natural state. Our strategy was to take samples during low405 flow periods because of the stability of the $\delta^{18} \mathrm{O}_{\mathrm{w}}$ value and the temperature, but there is still the question of how to choose appropriate time points when calculating the theoretical

407 equilibrium values with equation 2. This is also relevant for soils where sharp variations in the $408 \delta^{18} \mathrm{O}_{\mathrm{w}}$ value in the soil surface layers due to the progressive evaporation of the soil water 409 (Hsieh et al., 1998) might be a major source of uncertainty. Amelung et al. (2015) suggest 410 calculating the equilibrium $\delta^{18} \mathrm{O}_{\mathrm{p}}$ value with the annual average $\delta^{18} \mathrm{O}_{\mathrm{w}}$ for rainwater, arguing 411 that the biological recycling of Ca-bound $\mathrm{P}$ in soil is a long-term process. Using an annual 412 rainwater $\delta^{18} \mathrm{O}_{\mathrm{w}}$ value and temperature values, the calculated equilibrium value for the 413 agricultural soil samples (10 and 11 ) would increase by approximately $+2 \%$, resulting in 414 measured signatures below the equilibrium.

415 Except for a small number of studies (Elsbury et al., 2009; Gooddy et al., 2016; Markel et al., 416 1994; McLaughlin et al., 2006a), freshwater ecosystems have been poorly explored in terms of $417 \delta^{18} \mathrm{O}_{\mathrm{p}}$. Our results expand the global $\delta^{18} \mathrm{O}_{\mathrm{p}}$ library for these systems, comparing, for the first 418 time, the oxygen isotope signatures of HCl-P extracted from river sediment samples from 419 upstream to downstream with those of the main potential allochthonous sources in the 420 catchment. The isotope signatures of the analyzed river sediments, ranging from +12.2 to $421+15.8 \%$ o, lie in the interval reported in previous studies, i.e. +8.6 to 22.5 (Markel et al., 1994), 
+12.4 to $23.5 \%$ (Davies et al., 2014) and +9.7 to $+20.0 \%$ (Tamburini et al., 2014). The same is true for our soil samples (Amelung et al., 2015; Tamburini et al., 2014; Zohar et al., 2010).

\subsection{Biological recycling versus tracing the sources using $\delta^{18} O_{p}$ values}

\subsubsection{Soils}

Tamburini et al. $(2012,2014)$ have shown that the HCl-P fraction in the upper and most biologically active part of the oldest soil of a chronosequence was formed by secondary minerals precipitated from Pi that were previously cycled by biota. The close-to-equilibrium $\delta^{18} \mathrm{Op}$ values measured in the agricultural soil samples (samples 10 and 11) can be viewed as evidence that biological cycling had a large impact on the HCl-P fraction (which represents roughly half of the $\mathrm{Pt}$ ) in these samples. The soil $\mathrm{P}$ is supplied by the parent material and fertilizations and is redistributed throughout the soil profile via biological activities. As the parent material is low in $\mathrm{Pt}, \mathrm{P}_{\mathrm{Olsen}}$ and $\mathrm{Po}$, the high concentrations observed in the topsoil sample (see Table 3), as in other cultivated soils, is the long-term result of the accumulation and transformation of $\mathrm{P}$ favoring a high $\mathrm{P}$ bioavailability, which supports the assumption of an

437 intense biological activity.

438 The most common fertilizers used in the area have $\delta^{18} \mathrm{O}_{\mathrm{p}}$ values that are higher $(16.2-22.5 \%$ ) or 439 lower (9.5\% ; Guyard 2010) than the values for the studied agricultural soils. Even if we cannot 440 exclude that the observed equilibrium values were only the result of a mixing between the 441 parent material (close to $+15.9 \%$ ) and a lighter fertilizer input, we assume that the fertilizer has

442 little influence because the fertilizer inputs are almost totally cycled over the long-term (> 1 443 year) and the amount applied is too small (2-3\% of the HCl-P soil stock) over the short-term 444 (one season).

445 The high and above-equilibrium $\delta^{18} \mathrm{O}_{\mathrm{p}}$ value in the wetland surface soil (sample 9) can also 446 reflect the impact of biota, e.g. plants. The $\delta^{18} \mathrm{O}_{\mathrm{p}}$ value for this sample (18.3\%o) cannot be 
explained by the mixing of any of the potential input materials present in the area (i.e. bank material or cultivated soil), as $+18.3 \%$ is too far outside the range of the values (11.8 and $15.8 \%$ ) recorded by these input materials. The only source with a sufficiently high $\delta^{18} \mathrm{O}_{\mathrm{p}}$ value would be plant-derived phosphate. Phosphate in plants is enriched in ${ }^{18} \mathrm{O}$, with the $\delta^{18} \mathrm{O}_{\mathrm{p}}$ values ranging from 28 to 31\%o (Pfahler et al., 2013; Tamburini et al., 2014). This suggests that the extracted fraction might partially originate from the release of $\mathrm{P}$ from plant litter, either directly or via decomposition. A significant fraction of this enriched $\mathrm{P}$ pool that is not taken up by microbes (Liang and Blake, 2006; Oberson and Joner, 2005) might have precipitated or been sorbed into the soil mineral pool. Interestingly, this sample had a particularly high Po concentration. Preferential sorption/desorption reactions with soil minerals could also have helped increase the $\delta^{18} \mathrm{O}_{\mathrm{p}}$ value for this sample. However, previous studies have reported both negative and positive fractionation associated with sorption (Jaisi et al., 2010; Melby et al., 2013b). In any case, this effect is probably too small ( $<1 \%$ ) to justify the observed value by itself.

When compared to the equilibrium values calculated using the average river conditions (the values in brackets in Table 3, Fig. 2b), the subsoil/embankment sample and the wetland topsoil are no longer found within the equilibrium range. The situation is different for the agricultural topsoil sample, the actual $\delta^{18} \mathrm{O}_{\mathrm{p}}$ value of which falls within the equilibrium range, meaning that under these conditions the oxygen isotopic composition alone would not help to distinguish between a sedimentary $\mathrm{P}-\mathrm{PO}_{4}$ pool inherited from this soil and in-stream recycled $\mathrm{P}^{-\mathrm{PO}_{4}}$.

4.2.2 River sediments upstream and downstream from the wastewater treatment plant discharge

470 The September sampling showed that the input of $\mathrm{P}$ from wastewater was marked by a 471 threefold increase in the SRP concentration in the river water sampled upstream and 
downstream from the discharge point (Table 1), accompanied by a drastic change in the Pt, Pi and $\mathrm{P}_{\mathrm{Olsen}}$ concentrations in the corresponding sediments (Table 3). No changes were detected in the Po content, meaning that the impact of the point discharge on this pool in the bed sediments was negligible (Dorioz et al., 1998a). Interestingly, despite the small distance $(<100$ m) separating the upstream and downstream sites, the $\delta^{18}$ Op values were also distinct, with a difference of 3\%o. Upstream from the WWTP discharge point, the P pools in the sediment are mainly impacted by sources comprising a mixture of riverbanks and agricultural soil erosion (materials similar to samples 12 and 1,2$)$. The $\delta^{18} \mathrm{Op}$ value $(12.2 \%$ ) and $\mathrm{P}$ speciation for sample 4 were intermediate between those of these source materials.

The two September samples (4 and 5, immediately upstream and downstream from the WWTP) deviate from the isotopic equilibrium values (by -1.5 and $+1.4 \%$, respectively; Fig. $2 \mathrm{~b}$ ), suggesting the existence of conditions that prevent the complete biological turnover of $\mathrm{P}$ at both sites (also see Gooddy et al., 2016). Under the assumption that biological equilibration is the dominant process during sewage treatment (Gruau et al., 2005), the $\delta^{18}$ Op value for dissolved Pi from the WWTP would vary between 13.0 and $14.8 \%$ o using equation 2 (confirmed by the value of $14.0 \%$ measured by Guyard, 2010), meaning that the higher $\delta{ }^{18}$ Op value downstream (15.8\%o) cannot be interpreted as the result of a mixing between wastewater derived $\mathrm{P}$ and $\mathrm{P}$ from the upstream sediments. One possible explanation for this could be that part of the Pi injected into the river by the WWTP is rapidly (within a few meters from the injection point) and continuously sorbed onto the sediment particles, as also hypothesized by Dorioz et al. (1998a), and that the heavier isotopologues are preferentially sorbed. However, there is no consensus regarding the associated fractionation (Jaisi et al., 2010; Melby et al., 2013b). An alternative explanation would be that the upstream sample 4 represents a local anomaly, and the signature of the downstream sediments, sample 5, derives from local riverbank erosion. Sample 12 can be considered as representative of riverbank material and its $\delta{ }^{18} \mathrm{Op}$ value is comparable 
to that of sample 5. However, this hypothesis is unlikely as it does not explain the drastic change in P speciation observed in the sediments downstream from the WWTP (see Table 3). Only the locality situated immediately downstream from the WWTP discharge point could be sampled in March 2012 (sample 6). The SRP, Pt, Pi and $\mathrm{P}_{\text {Olsen }}$ concentrations were as high as those found in sample 5, which was collected in September, and much higher than the concentrations measured further upstream, at location 3, once again providing evidence for the strong impact of the WWTP discharge on the river and sediment P pool. The $\delta^{18} \mathrm{Op}$ value for sample 6 was similar to the September sample (sample 5), although it was close to the calculated isotopic equilibrium. The lack of a reference value equivalent to sample 4 in March means that it is not possible to conclude whether the observed value resulted from the complete equilibration of the sedimentary $\mathrm{P}-\mathrm{PO}_{4}$ pool or if it was instead produced by selective sorption processes as we suggest for sample 5. A repeated seasonal sampling of the sediments immediately upstream and downstream from the WWTP could possibly clarify this point.

\subsubsection{Head and outlet sediments}

The possible mixing of isotopically different sediment source materials coupled with differences in the sediment retention time complicates the interpretation of the $\delta^{18}$ Op values for the riverbed sediments. Under conditions of low biological activity and a short residence time, the isotopic signature of the sediments is expected to represent primary source signatures. In this context, an isotopic disequilibrium would indicate the existence of factors that limit the instream $\mathrm{P}$ cycling, intended as uptake by the biota, intracellular equilibration and subsequent release. As judged from the present data, a limiting situation for in-stream P recycling could have been prevalent in the head of the Redon River catchment, where strong out-of-equilibrium $\delta^{18} \mathrm{Op}$ signatures have been recorded (see Table 3 and Fig. 2b). This could be first related to the physical conditions in this part of the catchment - high-energy stream (total renewal of the 
522

523

524

525

526

527

sediments with each storm flow) and a short distance from the sources, i.e. riverbanks - which both determined the short residence times. The oligotrophic state of the running water (SRP < $10 \mu \mathrm{g} \mathrm{P} / \mathrm{l}, \mathrm{NO}_{3}<0.5 \mathrm{mg} \mathrm{N} / \mathrm{l}$ ) and the low $\mathrm{P}$ bioavailability of the riverbed sediments (as indicated by low $\mathrm{P}_{\text {Olsen }}$ concentrations) could contribute to limit the development of benthic biota and thus $\mathrm{P}$ uptake and subsequent release. For the same reasons the contribution of extracellular mineralization of organic $\mathrm{P}$ is expected to be negligible. The lack of an isotopic difference and the small differences in the Pt, Pi and Po content between the riverbank sample (12) and the sediment sample (3) collected immediately downstream further confirms the direct filiation between the source and the sediment.

The hypothesis that a rapid transfer does not significantly modify the $\delta^{18}$ Op signature is further supported by the disequilibrium signature recorded in the streamlet samples 1 and 2 and their Pi, Po and $\mathrm{P}_{\text {Olsen }}$ concentrations, as all of these parameters are intermediate between the values found in the analyzed deep and topsoil samples. This suggests i) a mixed origin for these two sediment samples derived from both superficial soils and ditch banks or field embankments; and ii) that the biological activity was not intense or not long enough to equilibrate the original P oxygen isotope signatures, consistently with the expected very short residence time of the sediments in the streamlets (stream order of 1).

The situation was different for the sediments that were collected closer to the river outlet or in the lake (stream order higher than 3). Close-to-equilibrium values were found in these samples. A corresponding increase in the SRP concentration in running water (a factor of 8 between upstream and the outlet; see Table 1), as the result of the cumulative anthropogenic inputs in the river, was also observed.

The equilibrium values observed in the lowest part of the Redon River suggest the occurrence of processes that are able to efficiently recycle the sedimentary $\mathrm{P}_{-} \mathrm{PO}_{4}$. This hypothesis would be consistent with the decrease in the $\delta^{18}$ Op values observed during the September campaign 
547 downstream from the WWTP discharge point, i.e. between samples 5 and 8 . There was a $3 \%$

548 decline in the $\delta^{18} \mathrm{Op}$ value between sample 5, which was collected immediately downstream

549 from the WWTP discharge point, and sample 8, which was collected approximately $2 \mathrm{~km}$

550 further downstream. This decrease was accompanied by a strong narrowing of the gap between

551 the measured and calculated equilibrium $\delta^{18}$ Op values. Whereas this gap was $+1.4 \%$ o for

552 sample 5, it was reduced to $<0.4 \%$ o for sample 8 (see Table 3 ). The isotopic equilibration

553 inferred by these data would likely occur in the sediments, given that in this kind of torrential

554 rivers most of the biological activity essentially takes place in the benthic system. Equilibration

555 could be further promoted by the longer residence time of the sediments in the downstream part

556 of the river (Dorioz et al., 1989). It may have been also driven by the enhanced bio-availability

557 of P in the lower part of the river, notably downstream from the WWTP, as evidenced by the

558 sharp increase in the $\mathrm{P}_{\text {Olsen }}$ concentration starting from this point (see Table 3, Figs. 2a and 2b).

559 Most likely, the overall process should be viewed more as the integration of a succession of

560 partial equilibrium occurring over different storage stages under similar equilibrium conditions,

561 as it is unlikely that the bulk of the $\mathrm{P}-\mathrm{PO}_{4}$ could be completely cycled by the benthic biota

562 during a single low-flow period.

563 However, we lack information about the real residence time of the sediments and the $\mathrm{P}$

564 recycling rates in the Redon River. Considering that the measured $\delta^{18} \mathrm{O}_{\mathrm{P}}$ values for the

565 sediments collected near the river outlet (samples 7 and 8) are identical within error to those

566 measured in the upstream streamlet sediments (samples 1 and 2) and are within the range of the

567 values found in the possible sediment sources (see Fig. 2a), we cannot entirely exclude that the

$568 \delta^{18} \mathrm{O}_{\mathrm{P}}$ values in these downstream sediments are simply source-inherited isotopic values. More

569 direct evidence for the real residence time of the sediments and the ability of aquatic biota to

570 efficiently recycle $\mathrm{P}_{-} \mathrm{PO}_{4}$ in the downstream part of the river is needed to decide between these

571 two hypotheses. 
We hypothesize that is possible to trace the potential sources of sediment particulate-P-PO 4 using oxygen isotopes, assuming a limited number of potential sources and under conditions of low biological activity and a short residence time in the river network. In the studied torrential system, it appeared possible to trace these sources in the head of the catchment (only two sources, rapid and high-energy transfer, limiting conditions for the biological activity). It would be also possible at the catchment scale, during winter high-flow periods, when the sediments that originate from banks and agricultural soil erosion are rapidly transferred as suspended matter and without significant interaction with point source discharge and biological activity. In this case, the $\delta^{18} \mathrm{Op}$ value would primarily be the result of a two end-members mixing between the cultivated soil (values close to 11-14\%o) and moraine material (values close to $15-16 \%$ ). However, the isotopic tracing is expected to be less straightforward during the summer and early fall periods, as the storm flows that occur at that time primarily mobilize riverbed sediments. Therefore, it could become more difficult to perform a quantitative assessment of 587 the original particulate-P sources using $\delta^{18}$ Op due to an overprinting of the sediment isotopic 588 signature induced by the high biological activity. During summer low flows, an even stronger 589 overprinting of the original isotopic signature is expected to occur in the downstream part of 590 the river, due to the input of anthropogenic, bioavailable $\mathrm{P}$, a longer sediment residence time 591 and increased biological activity. This being the case, $\delta^{18}$ Op could then instead be used as a 592 tool to assess the in-stream biological turnover of the P.

\section{Conclusion}


- In this study, we successfully adapted Tamburini et al.'s method (2010) for soil for use

597 with river sediments to provide the first assessment of the variability in $\delta^{18} \mathrm{Op}$ from HClextracted $\mathrm{P}$ in river sediments along a gradient of increasing anthropogenic impact.

- We observed a contrast between the $\delta^{18} \mathrm{Op}$ signature and the speciation of the sediments

600 collected in the head and at the outlet of the catchment. The sediments that were collected

601 upstream have isotopic signatures that are far from isotopic equilibrium and within the range of

602 the signatures found in the possible sediment sources (i.e. riverbank material), while those

603 collected at the outlet showed $\delta^{18} \mathrm{Op}$ values close to isotopic equilibrium. We related this

604 difference to the contrast between the highly dynamic character (short residence time) of the

605 transfer system in the head of the catchment (preservation of the isotopic signature of the

606 source material in the sediments) and the "quieter" sediment transport system in the lower

607 catchment, which, along with the input of the bioavailable anthropogenic P, likely fostered the

608 recycling of $\mathrm{P}$ by benthic biota, leading to an equilibration in the $\delta^{18} \mathrm{O}$ signatures. However,

609 with the available data, we cannot exclude that the signatures at the outlet were the result of the

610 mixing of sediments with higher (upstream/wetland sediments) and lower signatures

611 (agricultural soil erosion).

612 Uncertainties remain about the calculation of the equilibrium window. For aquatic

613 environments, the duration of the in-stream equilibration processes should be taken into

614 account, together with the perturbation caused by changes in the hydrological regime. This

615 would require an experimental approach for a proper estimation.

616 In terms of the quantitative tracing of potential particulate-P sources, future

617 investigations should focus on winter high flows, when rapid sediment transfer maximally

618 reduces the possibility of biological interactions. On the other hand, the sensitivity of $\delta^{18}$ Op to

619 biological processes opens up new promising perspectives for studying in-stream processes. In 
situ labelling experiments could help develop these studies by providing unique information about the biological uptake, turnover and/or organic P mineralization.

- $\quad$ More insights about the way and extent the biological activity controls P speciation in the soil and sediments could be possibly provided by the development of refined extraction methods that are able to selectively and quantitatively extract other P pools like the one associated with $\mathrm{Al}$ and Fe hydroxides, $\mathrm{P}_{\text {Olsen }}$ and Po or finer fractions (e.g. $<50 \mu \mathrm{m},<2 \mu \mathrm{m}$ ).

\section{Acknowledgments}

This work was funded by the EFPA department of INRA. The authors thank Philippe Quetin,

Pascal Perney and Danielle Lacroix (INRA, UMR CARRTEL) for their precious help and

Jerome Lazzarotto and Liliane Savoye for their advice and fruitful discussions. The authors acknowledge the EDYTEM Laboratory and in particular J.P. Jenny for providing the sediment samples from Lake Geneva.

\section{References}

Al-Charideh, A.R., 1988. Contribution à l'étude hydrologique du bassin du Redon, HauteSavoie : relation pluie-débit et quelques aspects isotopiques ( $\mathrm{PhD}$ Thesis). Université Pierre et Marie Curie, Paris.

Amelung, W., Antar, P., Kleeberg, I., Oelmann, Y., Lücke, A., Alt, F., Lewandowski, H., Pätzold, S., Barej, J.A.M., 2015. The $\delta{ }^{18} \mathrm{O}$ signatures of $\mathrm{HCl}$-extractable soil phosphates: methodological challenges and evidence of the cycling of biological P in arable soil: The $\delta{ }^{18} \mathrm{O}$ signatures of HCl-extractable soil phosphates. European Journal of Soil Science 66, 965-972. doi:10.1111/ejss.12288

Blake, R.E., O’Neil, J.R., Surkov, A.V., 2005. Biogeochemical cycling of phosphorus: insights from oxygen isotope effects of phosphoenzymes. American Journal of Science 305, 596-620. Burrus, D., Thomas, R.L., Dominik, J., Vernet, J.-P., 1989. Recovery and concentration of suspended solids in the upper rhone river by continuous flow centrifugation. Hydrol. Process. 3, 65-74. doi:10.1002/hyp.3360030107

Chang, S.J., Blake, R.E., 2015. Precise calibration of equilibrium oxygen isotope fractionations between dissolved phosphate and water from 3 to $37^{\circ} \mathrm{C}$. Geochimica et Cosmochimica Acta 150, 314-329. doi:10.1016/j.gca.2014.10.030 
CIPEL, 1988. Rapport de l'étude des pollutions diffuses dans le bassin lémanique. Commission Internationale pour la Protection des Eaux du Léman, Lausanne.

Davies, C.L., Surridge, B.W.J., Gooddy, D.C., 2014. Phosphate oxygen isotopes within aquatic ecosystems: Global data synthesis and future research priorities. Science of The Total Environment 496, 563-575. doi:10.1016/j.scitotenv.2014.07.057

Dorioz, J.M., Cassell, E.A., Orand, A., Eisenman, K.G., 1998a. Phosphorus storage, transport and export dynamics in the Foron River watershed. Hydrol. Process. 12, 285-309. doi:10.1002/(SICI)1099-1085(199802)12:2<285::AID-HYP577>3.0.CO;2-H

Dorioz, J.M., Ferhi, A., 1994. Pollution diffuse et gestion du milieu agricole: Transferts compares de phosphore et d'azote dans un petit bassin versant agricole. Water Research 28, 395-410. doi:10.1016/0043-1354(94)90277-1

Dorioz, J.M., Pelletier, J.P., Benoit, P., 1998b. Physico-chemical properties and bioavailability of particulate phosphorus of various origin in a watershed of lake Geneva. Water Research 2, 275-286.

Dorioz, J.M., Pilleboue, E., Ferhi, A., 1989. Dynamique du phosphore dans les bassins versants: Importance des phenomenes de retention dans les sediments. Water Research 23, 147-158. doi:10.1016/0043-1354(89)90038-9

Elsbury, K.E., Paytan, A., Ostrom, N.E., Kendall, C., Young, M.B., McLaughlin, K., Rollog, M.E., Watson, S., 2009. Using Oxygen Isotopes of Phosphate To Trace Phosphorus Sources and Cycling in Lake Erie. Environmental Science \& Technology 43, 3108-3114. doi:10.1021/es8034126

Ensign, S.H., McMillan, S.K., Thompson, S.P., Piehler, M.F., 2006. Nitrogen and phosphorus attenuation within the stream network of a coastal, agricultural watershed. J. Environ. Qual. 35, 1237-1247. doi:10.2134/jeq2005.0341

Fares, F., Fardeau, J.C., Jacquin, F., 1974. Quantitative survey of organic phosphorus in different soil types. Phosphorus in agriculture.

Feuillade, M., Dorioz, J.M., 1992. Enzymatic release of phosphate in sediments of various origins. Water Research 26, 1195-1201. doi:10.1016/0043-1354(92)90180-C

Goldhammer, T., Brunner, B., Bernasconi, S.M., Ferdelman, T.G., Zabel, M., 2011. Phosphate oxygen isotopes: Insights into sedimentary phosphorus cycling from the Benguela upwelling system. Geochimica et Cosmochimica Acta 75, 3741-3756. doi:10.1016/j.gca.2011.04.006 Gooddy, D.C., Lapworth, D.J., Bennett, S.A., Heaton, T.H.E., Williams, P.J., Surridge, B.W.J., 2016. A multi-stable isotope framework to understand eutrophication in aquatic ecosystems. Water Research 88, 623-633. doi:10.1016/j.watres.2015.10.046 Gruau, G., Legeas, M., Riou, C., Gallacier, E., Martineau, F., Hénin, O., 2005. The oxygen isotope composition of dissolved anthropogenic phosphates: a new tool for eutrophication research? Water Research 39, 232-238. doi:10.1016/j.watres.2004.08.035

Guyard, N., 2010. Contribution des méthodes isotopiques à la détermination des origines du phosphore apporté au Lac Léman (Master Thesis). Université de Savoie.

Hamid, S., Dray, M., Ferhi, A., Dorioz, J.M., Normand, M., Fontes, J.C., 1989. Etude des transferts d'eau à l'intérieur d'une formation morainique dans le bassin du Léman-Transferts d'eau dans la zone non saturée. Journal of Hydrology 109, 369-385.

Hsieh, J.C.C., Chadwick, O.A., Kelly, E.F., Savin, S.M., 1998. Oxygen isotopic composition of soil water: Quantifying evaporation and transpiration. Geoderma 82, 269-293. doi:10.1016/S0016-7061(97)00105-5

Jarvie, H.P., Neal, C., Williams, R.J., Neal, M., Wickham, H.D., Hill, L.K., Wade, A.J., Warwick, A., White, J., 2002. Phosphorus sources, speciation and dynamics in the lowland eutrophic River Kennet, UK. Science of The Total Environment, Water quality functioning of lowland permeable catchments:inferences from an intensive study of the River Kennet and upper River Thames 282-283, 175-203. doi:10.1016/S0048-9697(01)00951-2 
Jordan-Meille, L., 1998. Mode de transfert du phosphore d'origine diffuse dans un petit bassin rural lémanique (PhD Thesis). EPFL, Lausanne.

Kleinman, P.J.A., Sharpley, A.N., McDowell, R.W., Flaten, D.N., Buda, A.R., Tao, L., Bergstrom, L., Zhu, Q., 2011. Managing agricultural phosphorus for water quality protection: principles for progress. Plant Soil 349, 169-182. doi:10.1007/s11104-011-0832-9

Kronvang, B., Vagstad, N., Behrendt, H., Bøgestrand, J., Larsen, S.E., 2007. Phosphorus losses at the catchment scale within Europe: an overview. Soil Use and Management 23, 104-116. doi:10.1111/j.1475-2743.2007.00113.x

Liang, Y., Blake, R.E., 2006. Oxygen isotope signature of Pi regeneration from organic compounds by phosphomonoesterases and photooxidation. Geochimica et Cosmochimica Acta 70, 3957-3969. doi:10.1016/j.gca.2006.04.036

Longinelli, A., Nuti, S., 1973. Revised phosphate-water isotopic temperature scale. Earth and Planetary Science Letters 19, 373-376. doi:10.1016/0012-821X(73)90088-5

Markel, D., Kolodny, Y., Luz, B., Nishri, A., 1994. Phosphorus cycling and phosphorus sources in Lake Kinneret: tracing by oxygen isotopes in phosphate. Israel Journal of Earth Sciences 43, 165-178.

McLaughlin, K., Cade-Menun, B.J., Paytan, A., 2006a. The oxygen isotopic composition of phosphate in Elkhorn Slough, California: A tracer for phosphate sources. Estuarine, Coastal and Shelf Science 70, 499-506. doi:10.1016/j.ecss.2006.06.030

McLaughlin, K., Paytan, A., Kendall, C., Silva, S., 2006b. Oxygen isotopes of phosphatic compounds-Application for marine particulate matter, sediments and soils. Marine Chemistry 98, 148-155. doi:10.1016/j.marchem.2005.09.004

Melby, E.S., Soldat, D.J., Barak, P., 2013. Biological decay of 180-labeled phosphate in soils. Soil Biology and Biochemistry 63, 124-128. doi:10.1016/j.soilbio.2013.03.020

Mellander, P.-E., Jordan, P., Shore, M., Melland, A.R., Shortle, G., 2015. Flow paths and phosphorus transfer pathways in two agricultural streams with contrasting flow controls. Hydrol. Process. 29, 3504-3518. doi:10.1002/hyp.10415

Moorleghem, C.V., Schutter, N.D., Smolders, E., Merckx, R., 2013. The bioavailability of colloidal and dissolved organic phosphorus to the alga Pseudokirchneriella subcapitata in relation to analytical phosphorus measurements. Hydrobiologia 709, 41-53. doi:10.1007/s10750-013-1442-8

Nicoud, G., Coddet, E., Blavoux, B., Dray, M., 1993. Les complexes détritiques de marge glaciaire active du Bas Chablais oriental : implications hydrogéologiques . Quaternaire 4, 6976. doi:10.3406/quate.1993.1994

Oberson, A., Joner, E.J., 2005. Microbial turnover of phosphorus in soil, in: Organic Phosphorus in the Environment. CABI, Wallingford, pp. 133-164.

Olsen, S.R., Watanabe, F.S., Cosper, H.R., Larson, W.E., Nelson, L.B., 1954. Residual phosphorus availability in long-term rotations on calcareous soils. Soil Science 78, 141-152. Pacini, N., Gächter, R., 1999. Speciation of riverine particulate phosphorus during rain events. Biogeochemistry 47, 87-109. doi:10.1007/BF00993098

Pfahler, V., Dürr-Auster, T., Tamburini, F., M. Bernasconi, S., Frossard, E., 2013. ${ }^{18}$ O enrichment in phosphorus pools extracted from soybean leaves. New Phytologist 197, 186-193. doi:10.1111/j.1469-8137.2012.04379.x

Pistocchi, C., Silvestri, N., Rossetto, R., Sabbatini, T., Guidi, M., Baneschi, I., Bonari, E., Trevisan, D., 2012. A Simple Model to Assess Nitrogen and Phosphorus Contamination in Ungauged Surface Drainage Networks: Application to the Massaciuccoli Lake Catchment, Italy. Journal of Environment Quality 41, 544. doi:10.2134/jeq2011.0302 Pistocchi C., Tamburini F., Savoye L., Sebilo M., Baneschi I., Lacroix D., Perney P., Dorioz J.M., 2014. Développement d'une méthode d'extraction et purification des phosphates à partir 
de matrices sédimentaires pour l'analyse isotopique de leur oxygène. Le Cahier des Techniques de l'INRA 81,1.

Poulenard, J., Dorioz, J.-M., Elsass, F., 2008. Analytical Electron-Microscopy Fractionation of Fine and Colloidal Particulate-Phosphorus in Riverbed and Suspended Sediments. Aquatic Geochemistry 14, 193-210. doi:10.1007/s10498-008-9032-5

Poulenard, J., Perrette, Y., Fanget, B., Quetin, P., Trevisan, D., Dorioz, J.M., 2009. Infrared spectroscopy tracing of sediment sources in a small rural watershed (French Alps). Science of The Total Environment 407, 2808-2819. doi:10.1016/j.scitotenv.2008.12.049 Strahler A.N. 1957. Quantitative Analysis of Watershed Geomorphology. Transactions American Geophysical Union 28, 913-920. doi: 10.1029/TR038i006p00913 Saunders, W.M.H., Williams, E.G., 1955. Observations on the Determination of Total Organic Phosphorus in Soils. Journal of Soil Science 6, 254-267. doi:10.1111/j.13652389.1955.tb00849.x Sharpley, A.N., Gburek, W.J., Folmar, G., Pionke, H.B., 1999. Sources of phosphorus exported from an agricultural watershed in Pennsylvania. Agricultural Water Management 41, 77-89. doi:10.1016/S0378-3774(99)00018-9

Tamburini, F., Bernasconi, S.M., Angert, A., Weiner, T., Frossard, E., 2010. A method for the analysis of the $\delta 18 \mathrm{O}$ of inorganic phosphate extracted from soils with $\mathrm{HCl}$. European Journal of Soil Science 61, 1025-1032. doi:10.1111/j.1365-2389.2010.01290.x

Tamburini, F., Pfahler, V., Bünemann, E.K., Guelland, K., Bernasconi, S.M., Frossard, E., 2012. Oxygen Isotopes Unravel the Role of Microorganisms in Phosphate Cycling in Soils. Environmental Science \& Technology 46, 5956-5962. doi:10.1021/es300311h

Tamburini, F., Pfahler, V., von Sperber, C., Frossard, E., Bernasconi, S.M., 2014. Oxygen Isotopes for Unraveling Phosphorus Transformations in the Soil-Plant System: A Review. Soil Science Society of America Journal 78, 38. doi:10.2136/sssaj2013.05.0186dgs

Turner, B.L., Cade-Menun, B.J., Condron, L.M., Newman, S., 2005. Extraction of soil organic phosphorus. Talanta, Analysis of Phosphorus in Environmental and Agricultural Samples 66, 294-306. doi:10.1016/j.talanta.2004.11.012 Von Sperber, C., Kries, H., Tamburini, F., Bernasconi, S.M., Frossard, E., 2014. The effect of phosphomonoesterases on the oxygen isotope composition of phosphate. Geochimica et Cosmochimica Acta 125, 519-527. doi:10.1016/j.gca.2013.10.010

Von Sperber, C., Tamburini, F., Brunner, B., Bernasconi, S.M., Frossard, E., 2015. The oxygen isotope composition of phosphate released from phytic acid by the activity of wheat and Aspergillus niger phytase. Biogeosciences 12, 4175-4184. doi:10.5194/bg-12-4175-2015 Walling, D.E., Collins, A.L., Stroud, R.W., 2008. Tracing suspended sediment and particulate phosphorus sources in catchments. Journal of Hydrology, Characterization and apportionment of nutrient and sediment sources in catchments 350, 274-289. doi:10.1016/j.jhydrol.2007.10.047

Wang, D., Levine, S.N., Meals, D.W., Hoffmann, J.P., Drake, J.C., Cassell, E.A., 1999. Importance of Instream Nutrient Storage to P Export from a Rural, Eutrophic River in Vermont, USA, in: O.nley, T., L.nley, P. (Eds.), Lake Champlain in Transition: From Research Toward Restoration. American Geophysical Union, pp. 205-223.

Weiner, T., Mazeh, S., Tamburini, F., Frossard, E., Bernasconi, S.M., Chiti, T., Angert, A., 2011. A method for analyzing the $\delta 180$ of resin-extractable soil inorganic phosphate. Rapid Communications in Mass Spectrometry 25, 624-628. doi:10.1002/rcm.4899

Zohar, I., Shaviv, A., Young, M., Kendall, C., Silva, S., Paytan, A., 2010. Phosphorus dynamics in soils irrigated with reclaimed waste water or fresh water - A study using oxygen isotopic composition of phosphate. Geoderma 159, 109-121. doi:10.1016/j.geoderma.2010.07.002 
802

803

804

805

806

807 Table 1. Characteristics of the sediment sampling sites.

808

809

810

811

812

813

Table 2. Characteristics of the soil sampling sites.

Table 3. P speciation and oxygen isotope composition. locations, the numbers are the sample code. conditions). studied torrential system.

\section{Table and Figure captions}

Figure 1. Redon River catchment and sampling sites; the capital letters refer to the sampling

Figure 2. Oxygen isotope composition $\left(\delta^{18} \mathrm{O}_{\mathrm{p}}\right)$ and deviation from isotopic equilibrium. The gray circles represent potential source samples, white circles represent riverbed sediment samples, and Pols $=\mathrm{P}_{\mathrm{Olsen}} / \mathrm{P}_{\mathrm{t}}$ in $\%$ (note that the deviation of the potential sources from equilibrium in this image have been calculated according to the average within-river

Figure 3. Conceptual model describing the evolution of $\delta^{18} \mathrm{Op}$ for the riverbed sediments in the 
832

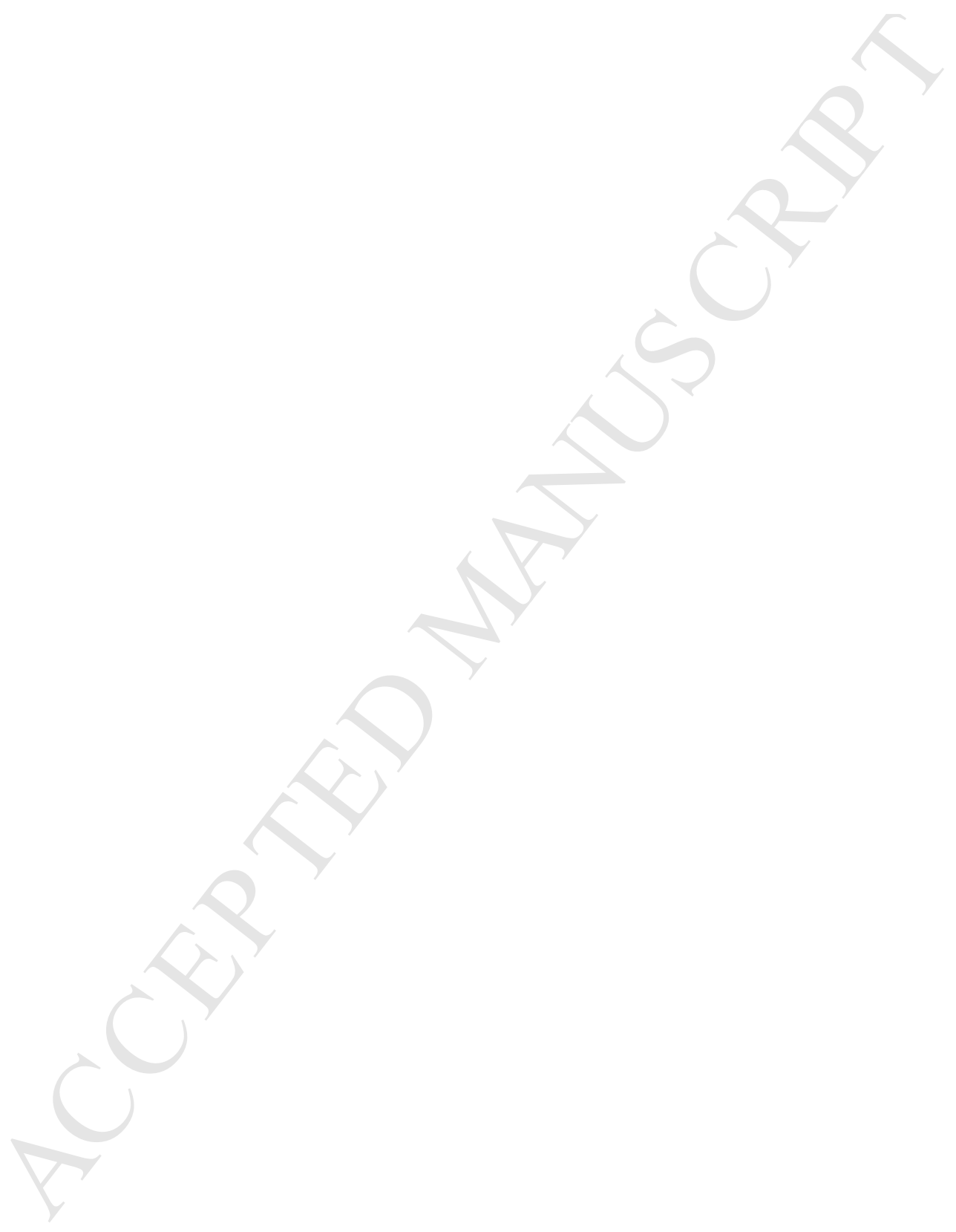


Table 1 Characteristics of sediment sampling sites

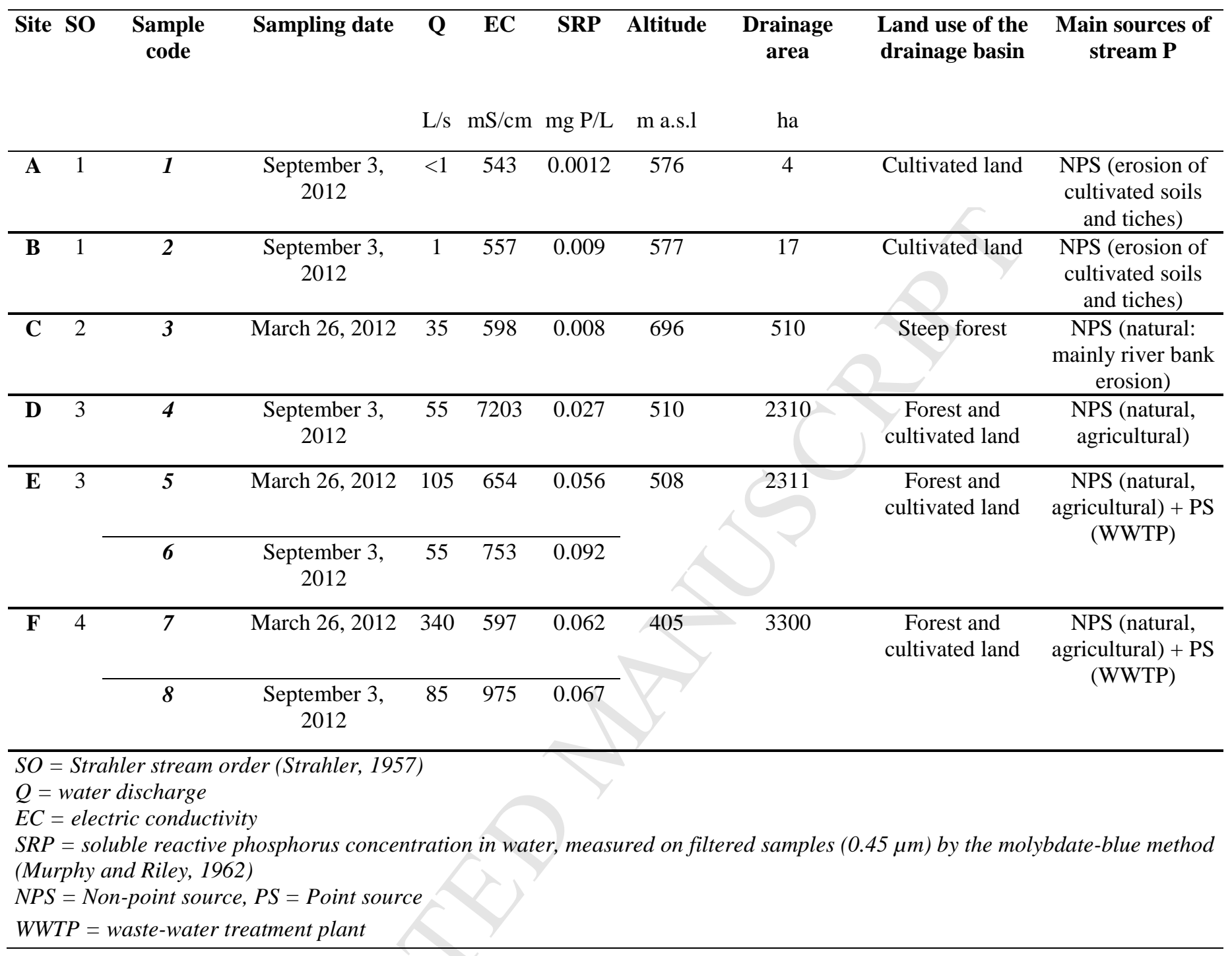


Table 2 Characteristics of soil sampling sites

\begin{tabular}{|c|c|c|c|c|c|}
\hline $\begin{array}{l}\text { Sample } \\
\text { code }\end{array}$ & Date of sampling & Location & $\begin{array}{l}\text { Soil } \\
\text { depth }\end{array}$ & $\begin{array}{l}\text { Altitude } \\
\text { m a.s.l }\end{array}$ & Sampling conditions \\
\hline 9 & September 3, 2012 & Wetland topsoil & -1 to -5 & 552 & Organic soil, saturated \\
\hline 10 & September 3, 2012 & Cultivated topsoil $^{\mathrm{a}}$ & $\begin{array}{l}-10 \text { to }- \\
30\end{array}$ & 558 & Cambisol on moraine deposit, dry \\
\hline 11 & September 3, 2012 & $\begin{array}{l}\text { Cultivated soil } \\
\text { (embankment) }^{\mathrm{a}}\end{array}$ & $\begin{array}{l}-60 \text { to }- \\
70\end{array}$ & 558 & $\begin{array}{l}\text { Cambisol on moraine deposit, } \\
\text { saturated }\end{array}$ \\
\hline 12 & September 3, 2012 & $\begin{array}{l}\text { Riverbank in a } \\
\text { forested upland area }\end{array}$ & - & 980 & Würm moraine deposits, saturated \\
\hline
\end{tabular}


Table 3. P speciation and oxygen isotopes composition

\begin{tabular}{|c|c|c|c|c|c|c|c|c|c|c|}
\hline $\begin{array}{l}\text { Sample } \\
\text { code }\end{array}$ & Sample type & $\mathrm{Pt}$ & $\mathrm{P}_{\text {Olsen }}$ & $\mathrm{Pi}$ & Po & $\mathrm{P}_{\text {Olsen }} / \mathrm{Pt}^{\mathrm{a}}$ & $\delta^{18} \mathrm{O}_{\mathrm{p}}$ & St. Dev. & $\mathrm{n}$ & $\begin{array}{l}\text { Deviation from } \\
\text { equilibrium }(\% o)^{\mathrm{b}}\end{array}$ \\
\hline & & $\mathrm{mgP} / \mathrm{kg}$ & $\mathrm{mgP} / \mathrm{kg}$ & $\mathrm{mgP} / \mathrm{kg}$ & $\mathrm{mgP} / \mathrm{kg}$ & $\%$ & $\%$ & $\%$ & - & $\%$ \\
\hline 1 & \multirow{8}{*}{$\begin{array}{l}\text { River bed } \\
\text { sediments }\end{array}$} & 791 & 14 & 401 & 180 & 2.4 & 12.5 & 0.3 & 3 & -2.4 \\
\hline 2 & & 751 & 20 & 323 & 208 & 3.8 & $13.3^{\$}$ & 0.3 & 2 & -1.6 \\
\hline 3 & & 528 & 8 & 411 & 78 & 1.7 & 15.5 & 0.6 & 4 & +1.3 \\
\hline 4 & & 609 & 18 & 398 & 202 & 2.9 & $12.2^{\$}$ & 0.4 & 2 & -1.5 \\
\hline 5 & & 1018 & 65 & 586 & 194 & 8.4 & $15.8^{\$}$ & 0.7 & 2 & +1.4 \\
\hline 6 & & 962 & 67 & 470 & 166 & 10.6 & 15.2 & 0.3 & 3 & $<0.4$ \\
\hline 7 & & 734 & 26 & 439 & 138 & 4.5 & 13.8 & 0.4 & 2 & $<0.4$ \\
\hline 8 & & 736 & 21 & 324 & 90 & 5.2 & 12.8 & 0.1 & 3 & -0.6 \\
\hline 9 & Wetland soil & 1163 & 32 & 179 & 383 & 5.7 & $18.3^{\$}$ & 0.2 & 2 & $+2.1(+3.6)^{\mathrm{c}}$ \\
\hline 10 & Agric. topsoil & 1256 & 43 & 631 & 450 & 6.2 & 14.0 & 0.4 & 2 & $<0.4(<0.4)^{\mathrm{c}}$ \\
\hline 11 & $\begin{array}{l}\text { Embankment/ } \\
\text { deep soil }\end{array}$ & 755 & 5 & 363 & 76 & 1.1 & 11.8 & 0.4 & 2 & $-0.7(-2.0)^{\mathrm{c}}$ \\
\hline 12 & $\begin{array}{l}\text { Riverbank } \\
\text { (moraine) }\end{array}$ & 511 & 3 & 305 & 36 & 0.7 & 15.9 & 0.2 & 2 & $+1.9(+1.2)^{\mathrm{c}}$ \\
\hline 13 & \multirow{2}{*}{$\begin{array}{l}\text { Lake } \\
\text { sediments }\end{array}$} & 459 & 15 & 365 & 121 & 3.5 & 12.9 & 0.3 & 2 & $<0.4$ \\
\hline 14 & & 539 & 17 & 420 & 70 & 3.1 & 13.9 & 0.5 & 2 & +0.8 \\
\hline
\end{tabular}

${ }^{a}$ As a sum of Pi and Po fractions

${ }^{b}$ See section 2.3.2 and equation 2

${ }^{c}$ Values not in brackets are calculated according to the temperature and water isotopes conditions at the sampling site, the values in brackets are calculated according to the "within-river" conditions

${ }^{d}$ Sediment samples are ranked according to the corresponding drained area 


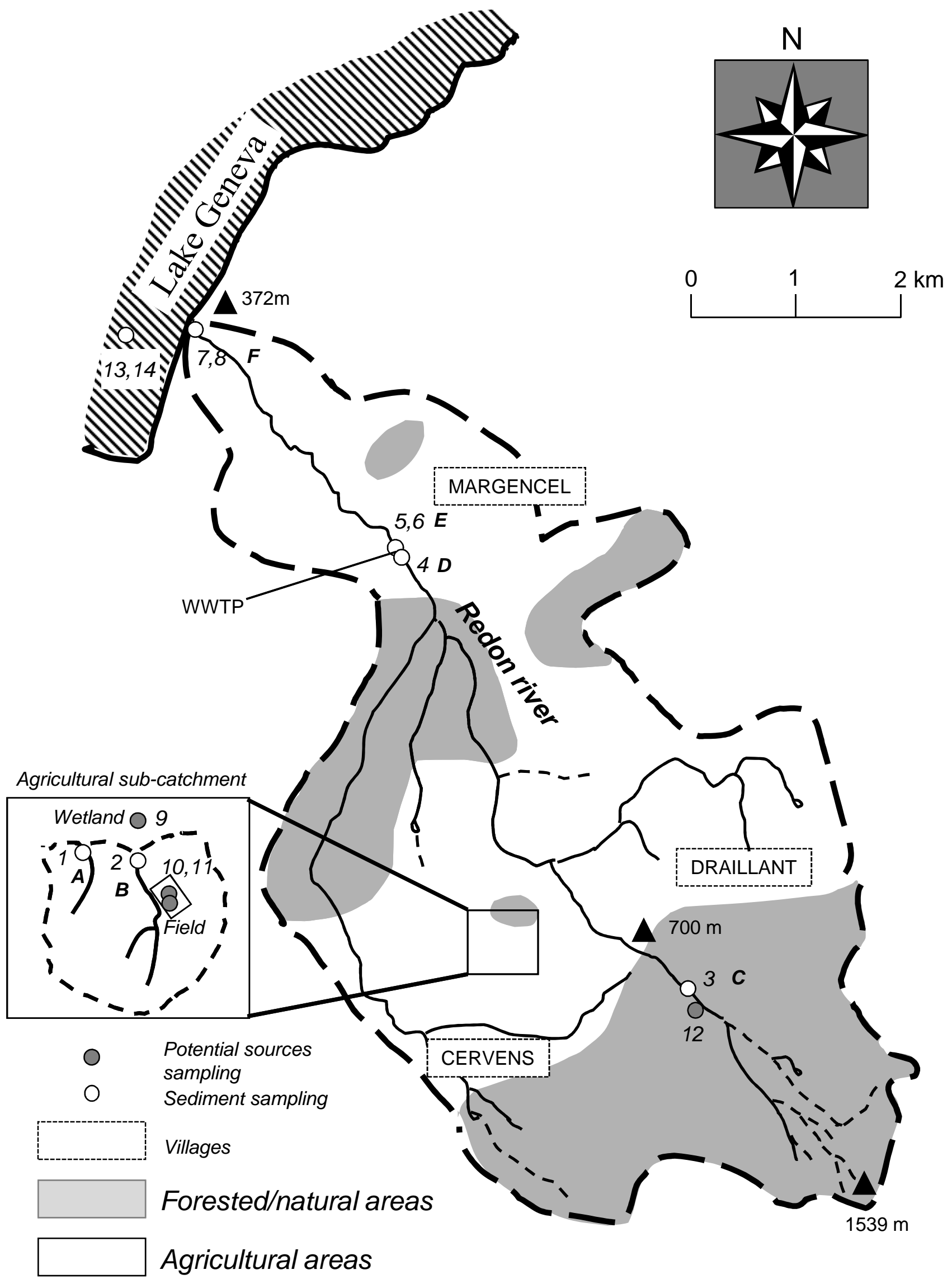

Figure 1. Redon River catchment and sampling sites, capital letters refer to sampling locations, numbers to sample code 


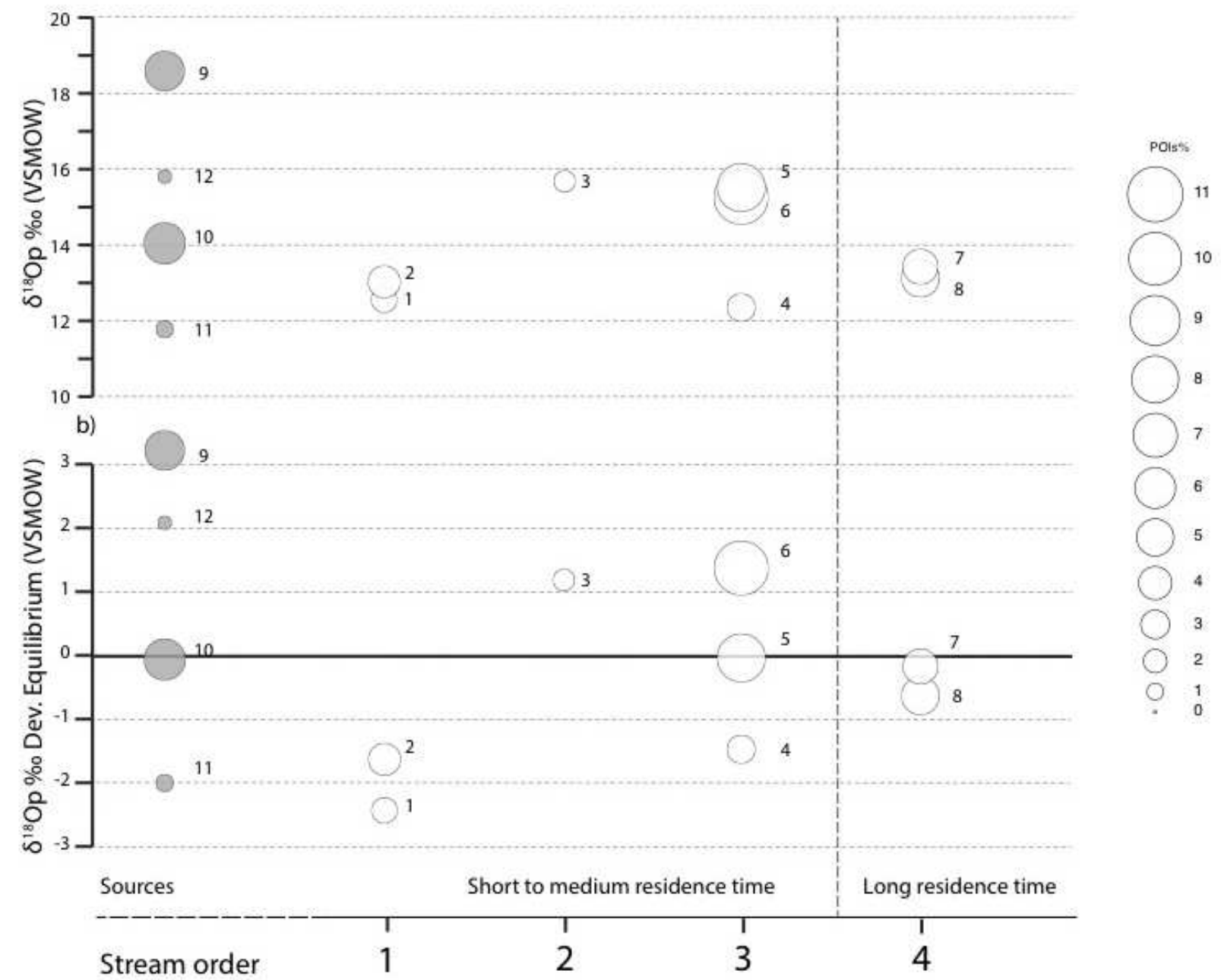

Figure 2. Oxygen isotopes composition $\delta^{18} \mathrm{Op}$ and deviation from isotopic equilibrium. Grey circles represent potential sources samples, white circles represent riverbed sediments samples, $\mathrm{P}_{\mathrm{ols}}=\mathrm{P}_{\text {Olsen }} / \mathrm{P}_{\mathrm{t}}$ in $\%$ (note that deviation from equilibrium of potential sources in this picture have been calculated according to average within-river conditions) 


\section{Highlights}

- We provided the first assessment of the oxygen isotopic composition of HCl-extracted phosphate in river sediments

- We observe a contrast in the oxygen isotope composition between upstream and downstream sediments

- This contrast can be related to anthropogenic impacts on the river system and to the sediment residence time

- We have shown that in some situations it is possible to trace particulate-P sources of sediments with this isotopic tool 